\title{
ASSESSMENT OF SELECTED METALS ENRICHMENT IN SEDIMENTS FROM PALEA KAVALA RIVER, NE MACEDONIA, NORTHERN GREECE
}

\author{
Giouri K. ${ }^{1}$, Vavelidis M. ${ }^{1}$, Melfos V. ${ }^{1}$ and Papadopoulou L. ${ }^{1}$ \\ ${ }^{1}$ Aristotle University of Thessaloniki, School of Geology, Department of Mineralogy-Petrology- \\ Economic Geology, 54124, Thessaloniki, Greece, agiouri@geo.auth.gr,vavelidi@geo.auth.gr, \\ melfosv@geo.auth.gr,lambrini@geo.auth.gr
}

\begin{abstract}
In surface aquatic systems, trace elements and especially heavy metals accumulate in sediments. Thus, the determination of sediment chemical characteristics is critical in the assessment of an aquatic environment's quality. Thirteen sediment samples from Palea Kavala river (NE Macedonia, Greece) were studied for their content in Al, Fe, $\mathrm{Cu}, \mathrm{Cd}, \mathrm{Mn}, \mathrm{Pb}, \mathrm{Zn}$. In order to evaluate the metal enrichment for environmental purposes, two geochemical indices were employed: Enrichment Factor (EF) and Geoaccumulation Index $\left(I_{\text {geo }}\right)$. According to the results, Al was the most abundant major element in sediments with $\mathrm{Fe}$ and Mn to follow. Trace element content followed the order $\mathrm{Pb}>\mathrm{Zn}>\mathrm{Cu}>\mathrm{Cd}$. EF values revealed that samples are enriched in $C d$ and $\mathrm{Pb}$, while $I_{g e o}$ values also suggested that there is considerable contamination concerning $\mathrm{Cd}$ and $\mathrm{Pb}$. It is concluded that ore mineralizations which occur in Palea Kavala region contribute to the elevated concentrations of all the studied elements, since they comprise mainly $\mathrm{Fe}-\mathrm{Mn}$ metal assemblages including minerals such as pyrite, goethite, chalcopyrite, galena, sphalerite and pyrolousite.
\end{abstract}

Keywords: Environmental geochemistry, Sediment contamination, Enrichment Factor, Northern Greece.

\section{Пері́ $\eta \psi \eta$}

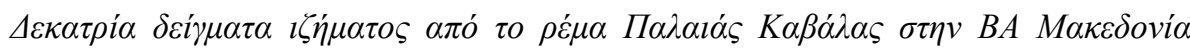

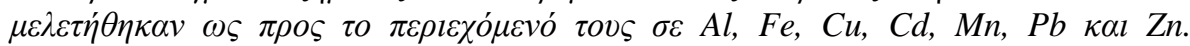

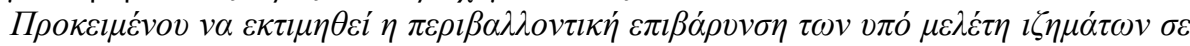

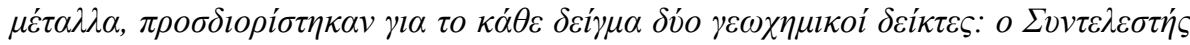

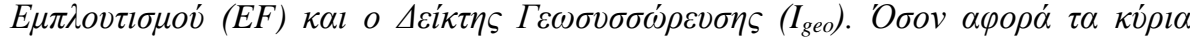

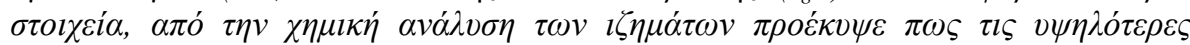

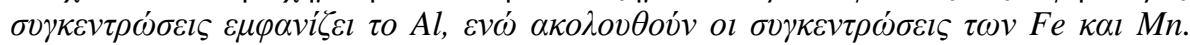

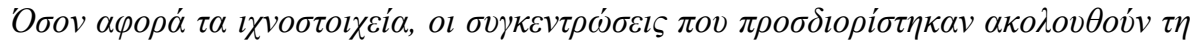

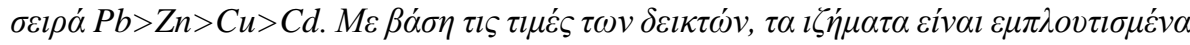

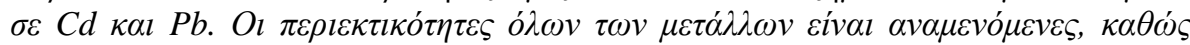

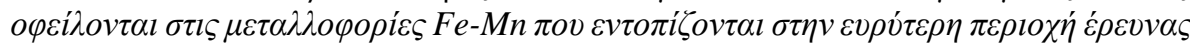

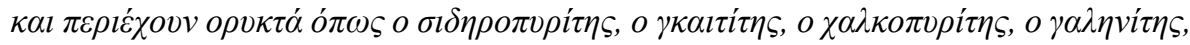

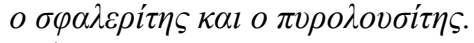

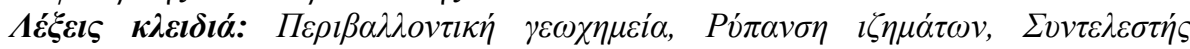

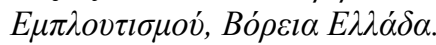




\section{Introduction}

Natural environment's contamination by trace elements, especially heavy metals, is of major concern to the society. These elements are not biodegradable and their presence in surface aquatic environment is attributed either to natural or anthropogenic sources. Heavy metals can be adsorbed by sediments through complex physical and chemical processes, acting both as carriers and potential sources of contaminants. The mechanisms by which metals accumulate in sediments, depend on the nature of the sediment and the properties of the adsorbed compounds. Hence, the determination of sediments' physicochemical characteristics is very important in the assessment of both the bioavailability of metals and the quality of the aquatic environment (Förstner, 1989; Laws, 1993; Calmano et al., 1996; KabataPendias, 2010). Various reference materials and enrichment calculation methods have been used by many researchers for the assessment of metal contamination in aquatic environments (Müller, 1981; Hakanson, 1980; Salomons and Förstner, 1984). Therefore, there is a considerable variation of methodologies in order to quantify metal contamination on a specific site.

The aim of the present study is to evaluate the enrichment of $\mathrm{Fe}, \mathrm{Cu}, \mathrm{Cd}, \mathrm{Mn}, \mathrm{Pb}$ and $\mathrm{Zn}$ in the sediments of Palea Kavala river and also to make a primary approach on the evaluation of its contamination status. Palea Kavala river is located $6 \mathrm{~km}$ north of the Kavala city, in northeastern Greece (Fig. 1). It emanates from the Lekani mountains and passing through the Palea Kavala village it flows towards the Philippoi plain. When entering the plain, due to the extensive karst formations, the river disappears into the sediments.

\section{Geological Setting}

Geotectonically the study area belongs to the lower Pangeon unit part of the Southern Core Complex and consists mainly of gneisses overlain by intercalations of marbles and schists. In the Palea Kavala area the metamorphic rocks were intruded by the Kavala pluton of a Lower Miocene age (21-22 Ma). The Kavala Pluton has the characteristics of an I-type intrusion and is mainly composed of amphibole-biotite granodiorite. Alluvial deposits which consist of clays, sands and gravels overlie the crystalline rocks (Christofides, 1996; Krohe and Boskos, 2002; Brun and Sokoutis, 2007; Burg, 2012; Melfos et al., 2008) (Fig. 1).

The Palea Kavala region contains 150 minor magmatic-hydrothermal base- and precious-metal occurrences within the Kavala pluton and the surrounding metamorphic rocks. These occurrences have variable metal assemblages that include Fe-Mn-( $\mathrm{Pb} \pm \mathrm{Zn} \pm \mathrm{Ag})$, Fe-Mn-Au, Fe-As-Au, Fe-Cu$\mathrm{Au}$ and $\mathrm{Bi}-\mathrm{Te}$, but they are mostly weathered and oxidized. Primary metallic minerals comprise pyrite, arsenopyrite, chalcopyrite, pyrrhotite, galena, sphalerite, tetrahedrite-tennantite, scorodite. Cosalite, pyrrhotite, bismuthinite, petzite, lillianite, proustite, pyrargyrite, argentite, jalpaite, stephanite and native gold are also included. Moreover, secondary minerals like goethite, covellite, arseniosiderite, pyrolusite, manganite, manganosite and cryptomelane contribute to the $\mathrm{Fe}$ and $\mathrm{Mn}$ content in the sediments resulting by the weathering of the surrounding rocks and the mineralizations that they comprise (Arvanitidis et al., 1989; Vavelidis et al., 1996a, b; Vavelidis et al., 1997; Melfos et al., 2008; Brun and Sokoutis, 2007; Fornadel et al., 2011). As Palea Kavala river flows towards the exit of its catchment area, it passes through extensive agricultural cultivated lands that grow on the Quaternary formations of the area and finally enters the sedimentary deposits of the Philippoi plain (Fig. 1).

\section{Materials and Methods}

\subsection{Sample Collection}

Thirteen sites were sampled for their sediment (PK1 to PK13) downstream the Palea Kavala river (Figure 1). Sediment samples were collected at the top of the riverbeds and their banks, avoiding the input of other materials. All sediment samples were collected with a plastic shovel and were placed in plastic bags, until they were delivered at the laboratory. 


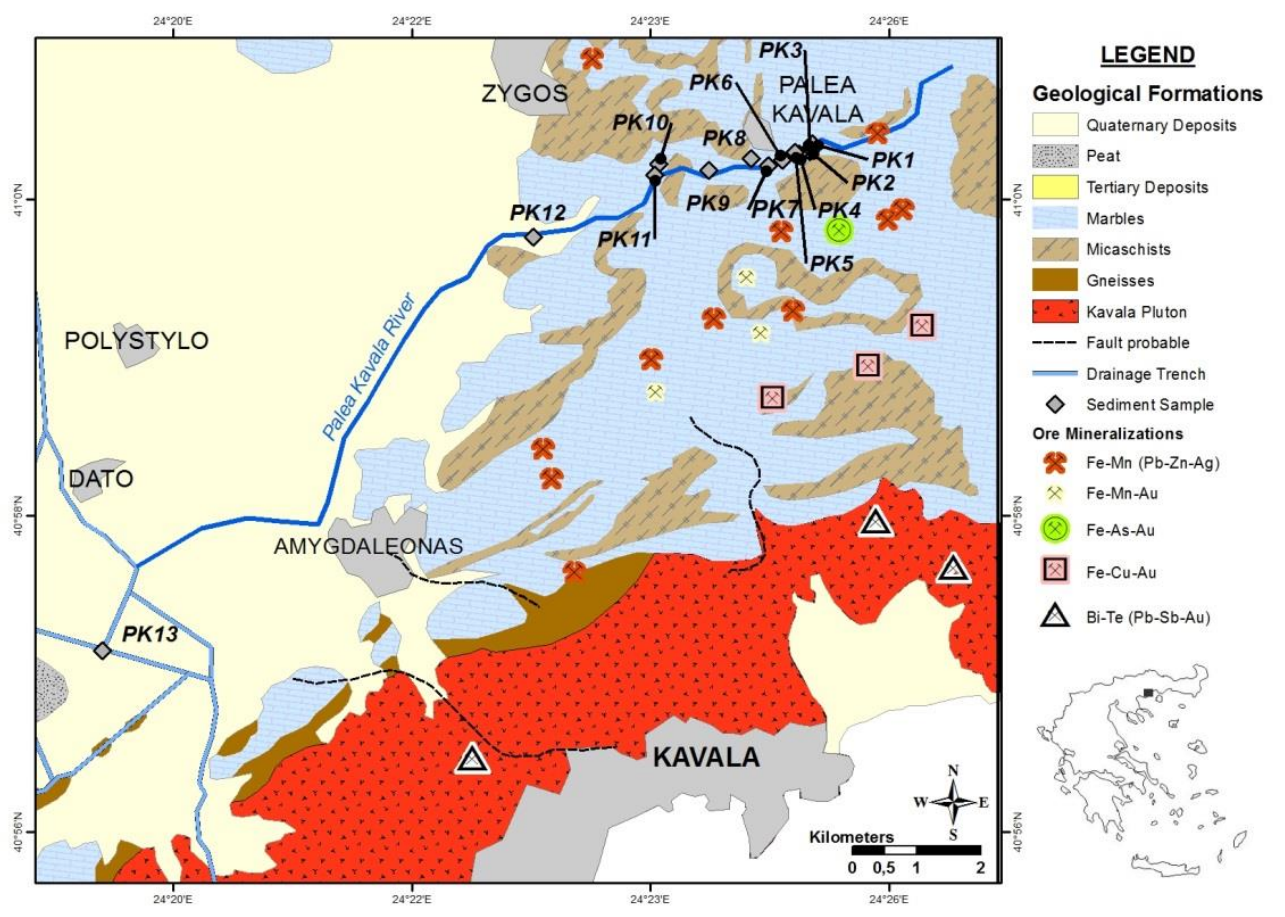

Figure 1 - Geological map of the studied area, including Palea Kavala river and sampling sites (according to Kronberg, 1970; Kronberg and Melidonis, 1970; Vavelidis, 1996a, b, 1997, with modifications).

\subsection{Sample Preparation}

In the laboratory the sediment samples were dried in an oven at $60^{\circ} \mathrm{C}$, so as to remove the adsorbed moisture. They were gently ground with pestle and mortar, in order to disaggregate the samples but not to break the grains themselves. Afterwards, the samples were sieved through a $0.063 \mathrm{~mm}$ sieve and stored in polyethylene bags until they were sent for analysis. Fine-grained sediments reveal large specific area. Consequently, inorganic contaminants and especially the environmentally available trace elements, remain mainly in this fraction. For that reason the $<0.063 \mathrm{~mm}$ fraction has been used by many researchers in order to investigate river pollution and likewise in the present study (Förstner and Salomons, 1991; Salomons, 1995; Kabata-Pendias, 2010).

\subsection{Sample Analysis}

In order to obtain their total content, determination of the major elements $\mathrm{Al}, \mathrm{Fe}$ and $\mathrm{Mn}$ was performed by X-Ray Fluorescence (XRF) at the Electron Microscopy Laboratory in the Faculty of Sciences, Aristotle University of Thessaloniki. For the application of the method, fused discs with a mixture of $35 \% \mathrm{Li}_{2} \mathrm{~B}_{4} \mathrm{O}_{7} / 65 \% \mathrm{LiBO}_{2}$ as a flux and $\mathrm{NH}_{4} \mathrm{I}$ as releasing agent were prepared for every sample. The mixture was placed into an $\mathrm{Au}-\mathrm{Pt}$ alloy crucible and heated at $1100^{\circ} \mathrm{C}$ with simultaneous agitation. Afterwards it was cast in an Au-Pt disc, mould and cooled in order to obtain the fused disc.

The concentrations of the trace elements $\mathrm{Cd}, \mathrm{Cu}, \mathrm{Pb}$ and $\mathrm{Zn}$ were determined by Inductively Coupled Plasma-Mass Spectrometry (ICP-MS), at the Acme Analytical Laboratories, in Vancouver, Canada. Metals in the sediments were extracted by using the aqua regia digestion, in order to solubilize all the elements that could become environmentally available. 


\subsection{Data Analysis}

To determine the metal enrichment in the sediments, Enrichment Factor (EF) and Geo-accumulation Index ( $\left.\mathrm{I}_{\mathrm{geo}}\right)$ were employed. The choice of background is very important in the calculation of both used indices. The normalizing elements often considered are $\mathrm{Fe}$ and $\mathrm{Al}$, because their concentrations are not affected by any contaminant inputs. But as it was mentioned above, the study area contains numerous Fe-enriched metal occurrences due to the presence of iron minerals (mainly pyrite, arsenopyrite, chalcopyrite, pyrrhotite, goethite). It is apparent therefore that there might be a slight enrichment in $\mathrm{Fe}$ in the Palea Kavala region, so $\mathrm{Al}$ was chosen as the reference element to normalize the metal concentrations. The geochemical background values used for calculating the indices are derived from those that were introduced by Turekian and Wedepohl (1961) as average shale content (Table 1).

The normalized enrichment factors (EF) were calculated according to the original Salomons and Förstner (1984) equation:

$$
E F=\frac{(\mathrm{Metal} / \mathrm{Al})_{\text {Sample }}}{(\mathrm{Metal} / \mathrm{Al})_{\text {Background }}}
$$

EF values were interpreted as suggested by Sakan et al. (2009), where: EF $<1$ indicates no metal enrichment; 1-3 there is minor enrichment; 3-5 there is moderate enrichment; 5-10 there is moderately severe enrichment; 10-25 there is severe enrichment; $25-50$ there is very severe enrichment; and >50 there is extremely severe enrichment.

The geo-accumulation Index $\left(\mathrm{I}_{\mathrm{geo}}\right)$ is defined as follows:

$$
I_{\text {geo }}=\log _{2}\left(\frac{C_{n}}{1.5 \times B_{n}}\right)
$$

where $\mathrm{Cn}$ is the measured concentration of the examined metal in sediment samples and $\mathrm{Bn}$ is the geochemical background concentration of the metal for the average shale. The 1.5 factor is the background matrix correction factor due to lithogenic effects (Muller, 1981; Loska and Wiechula, 2003). The Igeo values are classified in seven classes, according to Müller (1981). Class 0 (practically uncontaminated): $\mathrm{I}_{\text {geo }} \leq 0$; Class 1 (uncontaminated to moderately contaminated): $0<\mathrm{I}_{\text {geo }}<1$; Class 2 (moderately contaminated): $1<\mathrm{I}_{\text {geo }}<2$; Class 3 (moderately to heavily contaminated): $2<\mathrm{I}_{\text {geo }}<3$; Class 4 (heavily contaminated): $3<\mathrm{I}_{\text {geo }}<4$; Class 5 (heavily to extremely contaminated): $4<\mathrm{I}_{\mathrm{geo}}<5$; Class 6 (extremely contaminated): $\mathrm{I}_{\mathrm{geo}}>5$.

\section{Results and Discussion}

The results of this study are presented in Table 1 and Figure 2. Among the major elements, $\mathrm{Al}$ is th e most abundant demonstrating an average content of $6.61 \pm 1.65 \mathrm{wt} \%$. The second most abundant $\mathrm{e}$ lement is Fe with an average content of $4.46 \pm 1.05 \mathrm{wt} \%$. Concentrations of $\mathrm{Mn}(0.17 \pm 0.20 \mathrm{wt} \%$ in average) are very low in relation to $\mathrm{Al}$ and $\mathrm{Fe}$. In terms of the trace elements, the highest detected $\mathrm{c}$ oncentrations correspond to $\mathrm{Pb}$ (avg. $651.36 \pm 1104.89 \mu \mathrm{g} / \mathrm{g}$ ) and $\mathrm{Cu}$ (avg. 559.04 $\pm 1772.46 \mu \mathrm{g} / \mathrm{g}$ ). T

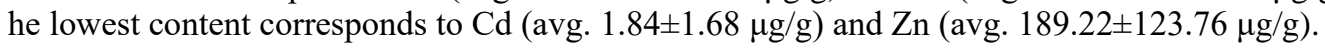


Table 1 - Statistical characteristics of the determined elements concentrations in all the studied samples.

\begin{tabular}{|c|c|c|c|r|r|r|r|}
\hline & $\begin{array}{c}\text { Al } \\
(\mathrm{wt} \%)\end{array}$ & $\begin{array}{c}\mathbf{F e} \\
(\mathrm{wt} \%)\end{array}$ & $\begin{array}{c}\text { Mn } \\
(\mathrm{wt} \%)\end{array}$ & $\begin{array}{c}\mathbf{C d} \\
(\mu \mathrm{g} / \mathrm{g})\end{array}$ & $\begin{array}{c}\mathbf{C u} \\
(\mu \mathrm{g} / \mathrm{g})\end{array}$ & $\begin{array}{c}\mathbf{P b} \\
(\mu \mathrm{g} / \mathrm{g})\end{array}$ & $\begin{array}{c}\mathbf{Z n} \\
(\mu \mathrm{g} / \mathrm{g})\end{array}$ \\
\hline Min & 3.49 & 2.37 & 0.06 & 0.50 & 38.38 & 75.68 & 74.50 \\
\hline Max & 8.42 & 5.87 & 0.79 & 6.34 & 6457.96 & 4240.92 & 539.80 \\
\hline Mean & 6.61 & 4.46 & 0.17 & 1.84 & 559.04 & 651.36 & 189.22 \\
\hline SD & 1.65 & 1.05 & 0.20 & 1.68 & 1772.46 & 1104.89 & 123.76 \\
\hline $\begin{array}{c}\text { Average } \\
\text { Shale }\end{array}$ & 8.00 & 4.72 & 0.085 & 0.3 & 45 & 20 & 95 \\
\hline
\end{tabular}

The elevated standard deviation that is mainly demonstrated by $\mathrm{Cu}, \mathrm{Pb}$ and to a lesser extent by $\mathrm{Zn}$ content is attributed to the extremely elevated concentrations that were determined for these eleme nts in only one sample. That is the sample PK13, which was collected downstream Palea Kavala ri ver in the sedimentary deposits of the Philippoi plain (Fig. 1). The concentrations determined in th at sample are $6457.96 \mu \mathrm{g} / \mathrm{g}$ for $\mathrm{Cu}, 4240.92 \mu \mathrm{g} / \mathrm{g}$ for $\mathrm{Pb}$ and $539.80 \mu \mathrm{g} / \mathrm{g}$ for $\mathrm{Zn}$. In order to evaluat $\mathrm{e}$ if those concentrations affect the statistical characteristics, the calculation of mean and standard $\mathrm{d}$ eviation values was repeated excluding the sample PK13.

According to the results, no significant variation was observed concerning the major elements. Mo re specifically, by excluding sample PK13 the average content is $6.74 \pm 1.64 \mathrm{wt} \%$ for $\mathrm{Al}, 4.59 \pm 0.97$ $\mathrm{wt} \%$ for $\mathrm{Fe}$ and $0.17 \pm 0.21 \mathrm{wt} \%$ for Mn, remaining in the same level with the corresponding values presented in Table 1. Similarly for Cd, its concentration determined in PK13 does not affect strong ly the statistical characteristics, since its exemption decreases the average $\mathrm{Cd}$ content slightly, from $1.84 \pm 1.68 \mu \mathrm{g} / \mathrm{g}$ to $1.74 \pm 1.71 \mu \mathrm{g} / \mathrm{g}$. Concerning the rest of the trace elements, significant variations were observed both in average content and standard deviation of $\mathrm{Cu}, \mathrm{Pb}$, and $\mathrm{Zn}$. By excluding sa mple PK13, $\mathrm{Cu}$ decreases from $559.04 \pm 1772.46 \mu \mathrm{g} / \mathrm{g}$ in average to $67.47 \pm 15.31 \mu \mathrm{g} / \mathrm{g}$. The average content of $\mathrm{Pb}$ decreases from $651.36 \pm 1104.89 \mu \mathrm{g} / \mathrm{g}$ to $352.23 \pm 250.56 \mu \mathrm{g} / \mathrm{g}$. Although in a smaller degree, variation is also observed in the calculated statistical parameters for $\mathrm{Zn}$, since its average $\mathrm{c}$ ontent decreases from $189.22 \pm 123.76 \mu \mathrm{g} / \mathrm{g}$ to $160.01 \pm 67.86 \mu \mathrm{g} / \mathrm{g}$.

It is apparent, therefore, that $\mathrm{Cu}, \mathrm{Pb}$ and $\mathrm{Zn}$ content in sample PK13 is extremely high compared to all the other studied samples. This is probably attributed to the fact that between the sampling sites PK12 and PK13, the Palea Kavala river passes through extensive agricultural cultivated lands. So, the use of pesticides, fertilizers and other agrochemical products which contain significant $\mathrm{Cu}, \mathrm{Pb}$ and Zn components, may explain such an elevated content (Baker, 1990; Ramalho et al., 2000).

The resulting EF and $\mathrm{I}_{\mathrm{geo}}$ values are presented in Figure $2 \mathrm{a}$ and $2 \mathrm{~b}$, respectively. According to the EF values, Fe exhibits minor enrichment. As demonstrated in Fig. 2a, there is a minor to extremely severe enrichment for $\mathrm{Cu}$, moderate to extremely severe enrichment for $\mathrm{Pb}$ and minor to moderately severe enrichment for Zn. It must be mentioned though, that these three elements show elevated concentrations in only one sample, PK13. As presented in Table 1 and discussed above, PK13 reveals maximum concentrations for $\mathrm{Cu}, \mathrm{Pb}$ and $\mathrm{Zn}$ which are extremely higher than their corresponding mean values, elevating EF values as well. Minor to very severe enrichment is observed for $\mathrm{Cd}$ and minor to severe enrichment for $\mathrm{Mn}$. In that case, maximum concentrations of $\mathrm{Cd}$ and $\mathrm{Mn}$ are not determined in sample PK13. They occur in other samples along Palea Kavala river since, as mentioned above, by excluding PK13 the mean content and standard deviation values of $\mathrm{Cd}$ and $\mathrm{Mn}$ do not demonstrate significant variation.

Overall, as demonstrated in Figure 2a it can be assumed that $\mathrm{Fe}, \mathrm{Cu}, \mathrm{Mn}$ and $\mathrm{Zn}$ enrichment is characterized as minor, since most of the EF values concerning those elements are plotted in that field. On the contrary, $\mathrm{Cd}$ and $\mathrm{Pb}$ appear to be enriched in the Palea Kavala river sediments (Fig. 2a). 

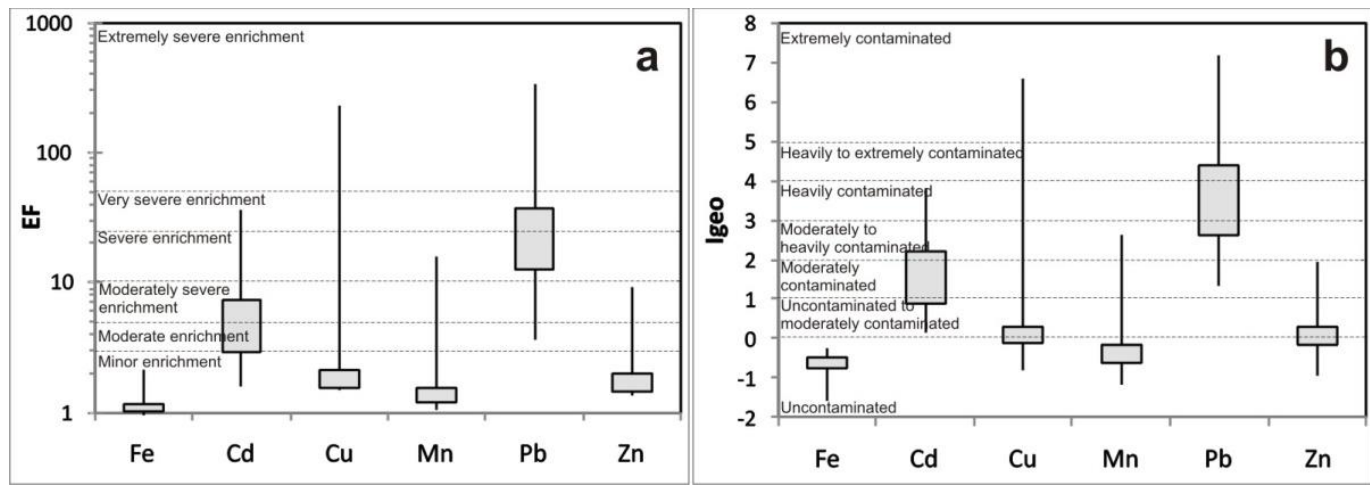

Figure 2 - Variations of values that resulted for (a) enrichment factors-EF and (b) geoaccumulation indexes $-\mathbf{I}_{\text {geo }}$.

Calculated $\mathrm{I}_{\text {geo }}$ values present similar distribution with EF values (Fig. 2b). The results indicate that the sediments are not contaminated with respect to $\mathrm{Fe}$. Moreover, $\mathrm{Cu}, \mathrm{Mn}$ and $\mathrm{Zn}$ levels range from uncontaminated to extremely contaminated, moderately-heavily contaminated and moderately contaminated, respectively. Finally, the sediments are uncontaminated-moderately to heavily contaminated with respect to $\mathrm{Cd}$ and moderately to extremely contaminated concerning $\mathrm{Pb}$. $\mathrm{I}_{\text {geo }}$ values of most elements demonstrate similar effect with EF values. Maximum concentrations that in certain cases are extremely higher than the corresponding mean values have as a consequence the elevation of $I_{\text {geo }}$ values. Based on the classification of most of the $I_{\text {geo }}$ values (Fir. $2 b$ ), sediments are mainly considered as uncontaminated regarding $\mathrm{Fe}$ and $\mathrm{Mn}$ with a degree of uncontaminated to moderately contaminated for $\mathrm{Cu}$ and $\mathrm{Zn}$. Concerning $\mathrm{Cd}$ and $\mathrm{Pb}$, most of $\mathrm{I}_{\text {geo }}$ values suggest that sediments are moderately to heavily contaminated.

Generally, the concentrations of all the studied elements are expected to be elevated, since they participate in the composition of metallic minerals contained in the ore mineralization that occurs in the study area. Minerals like pyrite, goethite and chalcopyrite increase the enrichment of $\mathrm{Fe}$ and $\mathrm{Cu}$, while $\mathrm{Pb}$ and $\mathrm{Zn}$ are attributed in galena and sphalerite, respectively. Since that ore mineralization includes mainly Fe-Mn metal assemblages (Vavelidis et al., 1997; Fornadel et al., 2011), Mn concentrations are expected as well due to the presence of pyrolousite, manganosite and manganite. Concerning $\mathrm{Cd}$, it is a common content of sphalerite, a mineral which is abundant in the region (Vavelidis et al., 1996a, b; Vavelidis et al., 1997; Melfos et al., 2008; Fornadel et al., 2011). Moreover, the extremely elevated concentrations of $\mathrm{Cu}, \mathrm{Pb}$ and $\mathrm{Zn}$ in site PK13 are more related with anthropogenic activities since they probably result due to the extensive use of agrochemical products, whereas $\mathrm{Cd}$ and $\mathrm{Mn}$ enrichment is mainly attributed to the geological environment.

\section{Conclusions}

The present study imposes a primary approach on the evaluation of the enrichment that sediments from Palea Kavala river (NE Macedonia, Northern Greece) may demonstrate, with respect to selected metals.

Concerning major elements, the most abundant is $\mathrm{Al}$ with Fe to follow. Among the trace metals, $\mathrm{Cd}$ and $\mathrm{Cu}$ reveal the lowest concentrations. As demonstrated by enrichment factor (EF) values, Palea Kavala river sediments are enriched in $\mathrm{Cd}$ and $\mathrm{Pb}$. The same result is also revealed by the $\mathrm{I}_{\text {geo }}$ values, according to which the sediments are uncontaminated-moderately to heavily contaminated with respect to $\mathrm{Cd}$ and moderately to extremely contaminated concerning $\mathrm{Pb}$. The presence of extended ore mineralization which among others includes as primary metallic minerals pyrite, chalcopyrite, galena, sphalerite, pyrolusite, manganosite and manganite, probably affect the $\mathrm{Fe}, \mathrm{Cu}, \mathrm{Pb}, \mathrm{Zn}, \mathrm{Cd}$ and $\mathrm{Mn}$ content in sediments. However, maximum concentrations of $\mathrm{Cu}, \mathrm{Pb}$ and $\mathrm{Zn}$, which are extremely higher than their corresponding mean values, do not seem having a natural origin. Unlike 
all the other determined metals, they are probably related with anthropogenic activities and more specifically with the use of agrochemical products.

However, the research in the study area is in progress for a more detailed evaluation on the mineralogical composition of the sediments and on the correlation among the metal concentrations that they comprise.

\section{Acknowledgments}

The first author (Giouri K.) would like to thank the State Scholarships Foundation of Greece for the financial support during her post-graduate studies.

\section{References}

Arvanitidis, N., Kosmas, C., Eliopoulos, D., Perdikatsis, V. and Economou, G., 1989. Gold mineralization associated with carbonate-hosted polymetallic gossans in the area of Kavala, Geologica Rhodopica, 340-349.

Baker, D.E., 1990. Copper, In: Alloway, B.J., eds., Heavy metals in soils, 151-176, Glasgow/London/New York, Blackie/Wiley, 339 pp.

Brun, J.P. and Sokoutis, D., 2007. Kinematics of the Southern Rhodope Core Complex (North Greece, International Journal of Earth Sciences, 96(6), 1079-1099.

Burg, J.P., 2012. Rhodope: From Mesozoic convergence to Cenozoic extension, Review of petrostructural data in the geochronological frame. In: Skourtsos, E. and Gordon, S.L., eds., The Geology of Greece, Journal of the Virtual Explorer, 42(1), 44 pp.

Calmano, W., Ahlf, W. and Förstner, U., 1996. Sediment quality assessment: chemical and biological approaches. In: Calmano, W. and Förstner, U., eds., Sediments and Toxic Substances, 1-35. Springer Verlag, Berlin.

Christofides, G., 1996. Tertiary magmatism in the Greek Rhodope Massif, northern Greece: Granitic plutons. In: Knezevic, V. and Krstic, B., eds., Terranes of Serbia: The Formation of the Geologic Framework of Serbia and the Adjacent Regions, University of Belgrade, Belgrade, 155-160.

Fornadel, A.P., Spry, P.G., Melfos, V., Vavelidis, M. and Voudouris, P., 2011. Is the Palea Kavala $\mathrm{Bi}-\mathrm{Te}-\mathrm{Pb}-\mathrm{Sb} \pm \mathrm{Au}$ district, northeastern Greece, an intrusion-related system? Ore Geology Reviews, 39, 119-133.

Förster, U. and Salomons, W., 1991. Mobilization of metals from sediment. In: Merian, E., ed., Metals and their compounds in the environment, 379-398, VCH, Weinheim.

Förstner, U., 1989. Contaminated sediment. In: Bhattacharij, S. ed., Lecture Notes in Earth Sciences, 1-157, Springer, Berlin.

Hakanson, L., 1980. Ecological risk index for aquatic pollution control, a sedimentological approach, Water Research, 14, 975-1001.

Kabata-Pendias, A., 2010. Trace elements in soils and plants, 4th Edition, CRC Press, 548 pp.

Krohe, A. and Mposkos, E., 2002. Multiple generations of extensional detachments in the Rhodope Mountains (northern Greece): evidence of episodic exhumation of high-pressure rocks. In: Blundell, D.J., Neubauer, F. and von Quadt, A., eds., The timing and location of major ore deposits in an evolving orogen, 204, 151-178, Geological Society, London. 
Kronberg, P., 1970. Geological map of Greece: Kavala Sheet, Scale 1:50.000. IGME, Athens.

Kronberg, P. and Melidonis, N., 1970. Geological map of Greece: Krinidhes Sheet, Scale 1:50.000. IGME, Athens.

Laws, E.A., 1993. Aquatic Pollution: An Introductory Text, 2nd Edition, John Wiley and Sons, Inc., New York, $611 \mathrm{pp}$.

Loska, K. and Wiechula, D., 2003. Application of principal component analysis for the estimation of source of heavy metal contamination in surface sediments from the Rybnik Reservoir, Chemosphere, 51, 723-733.

Melfos, V., Voudouris, P., Vavelidis, M. and Spry, P.G., 2008. Microthermometric results and formation conditions of a new intrusion-related $\mathrm{Bi}-\mathrm{Te}-\mathrm{Pb}-\mathrm{Sb} \pm \mathrm{Au}$ mineralization in the Kavala Pluton, Greece, Joint 13th All-Russian Conference on Thermobarogeochemistry/ 4th Asian and Pacific International Fluid Inclusion Society Symposium, Moscow, Abstracts.

Müller, G., 1981. Die Schwermetallbelstung der sedimente des Neckars und seiner Nebenflusse: eine Bestandsaufnahme, Chemicer-Zeitung, 105, 157-164.

Ramalho, J.F.G.P., Sobrinho, N.M.B. and Velloso, A.C.X., 2000. Heavy metals contamination of a watershed in Caetés by the use of agrochemicals, Pesquisa Agropecuária Brasileira, 35(7), 1289-1303.

Sakan, S.M., Djordjevic, D.S., Manojlovic, D.D. and Polic, P.S., 2009. Assessment of heavy metal pollutants accumulation in the Tisza river sediments, Journal of Environmental Management, 90(11), 3382-3390.

Salomons, W., 1995. Environmental impact of metals derived from mining activities: processes, predictions, preventions, Journal of Geochemical Exploration, 52, 5-23.

Salomons, W. and Förstner, U., 1984. Metals in the hydrocycle, Berlin/Heidelberg/Tokyo, Springer, 349 pp.

Turekian, K.K. and Wedepohl, K.H., 1961. Distribution of the elements in some major units of the earth's crust, Bulletin of the Geological Society of America, 72, 175-192.

Vavelidis, M., Christofides, G. and Melfos, V., 1996a. The Au-Ag-bearing mineralization and placer gold of Palea Kavala (Macedonia, N. Greece). In: Knežević-Dorđević, V. and Krstić, B., eds., Terranes of Serbia, The Formation of the Geologic Framework of Serbia and the Adjacent Regions, University of Belgrade, Belgrade, 311-316.

Vavelidis, M., Gialoglou, G., Melfos, V. and Wagner, G.A., 1996b. Goldgrube in Palaea KavalaGriechenland: Entdeckung von Skaptehyle? Erzmetall, 49, 547-554.

Vavelidis, M., Melfos, V. and Eleftheriadis, G., 1997. Mineralogy and microthermometric investigations in the Au-bearing sulphide mineralization of Palea Kavala (Macedonia, Greece). In: Papunen, H., eds., Mineral Deposits: Research and Exploration - Where do They Meet? 343-346, Balkema, Rotterdam. 